\title{
Efforts to Support Sustainable Agriculture with The Understanding of Invasion and Colonization Egg Parasitoid of Yellow Rice Stemborer, Scirphopaga Incertulas Walker (Lepidoptera: Pyralidae) in Bali
}

\author{
Ni Made Delly Resiani \#, I Wayan Supartha \#, I Nyoman Wijaya \#, I Wayan Laba* \\ \# Postgraduate, Udayana University, Denpasar, Indonesia \\ dellyresiani@yahoo.co.id; yansupartha@yahoo.com;dewiwijayanti0312@yahoo.com \\ * Research Institute for Spices and Medicinal Crops, Bogor, Indonesia \\ E-mail:wayan_laba@yahoo.com
}

\begin{abstract}
The arrangement of sustainable agriculture in Bali which appropriate with Bali government's mission: Bali Clean and Green "Go to Organic". The concept of modern agriculture looks like contradiction with the aspects of sustainable agriculture. The aspects of rice cultivation have been done by local agriculture community in Bali (call it SUBAK) for many years, but the attack of yellow rice stemborer still happen, which adverse farmer's side, persist. The efforts control which has been done, still rely on insecticides because it can give quick effect, but it is not appropriate for sustainable agriculture. The other solution to solve that issue is with the integrated pest management (IPM), as the main component of which is the role of parasitoids. Therefore needed research to investigate the invasion and colonization of yellow rice stemborer parasitoids in Bali. The research was conducted in three districts centers of rice stemborer (Badung, Tabanan, Jembrana), since December 2013 to March 2014. This research using survey method with the rule is collecting the group of egg with purposive random sampling at 10 - 66 days after planting (dap), as many as 70 groups of eggs per week. The observed of variables include the percentage of infected eggs, diversity, dominance, similarity, abundance, attack level and ratio of female parasitoids. The result showed that invasion and colonization of the egg parasitoid of yellow rice stemborer in Bali vary in diversity, dominance, abundance, the percentage of infected eggs and attack level. Three types of parasitoids associated with rice plants, they are Trichogramma japonicum, Telenomus rowani and Tetrastichus schoenobii. The percentage of infected eggs, diversity, dominance of $T$. japonicum, $T$. rowani and $T$. schoenobii, similarity, abundance of $T$. japonicum, T. rowani and T. schoenobii, attack level of $T$. japonicum, $T$. rowani and $T$. schoenobii and ratio of female of $T$. japonicum, T. rowani and T. schoenobii found in Tabanan regency, were $(90.14 \% ; 0.32 ; 0.00 ; 0.06 ; 0.49 ; 100 \% ; 96.16 ; 424.09$; $1.193,54$ tail; $1.30 ; 11.98 ; 85.13 \% ; 77.36 ; 84.67 ; 79.51 \%)$, in Badung regency were found $(83.68 \% ; 0.42 ; 0.02 ; 0.12 ; 0.26 ; 100 \%$; 199.94; 471.14; 708.83 tail; 5,$22 ; 20,61 ; 64,25 \% ; 76.48 ; 83.44 ; 77.63 \%)$ and at Jembrana regency were found $(78.61 \% ; 0.39 ; 0.02 ; 0.35 ; 0.07 ; 100 \% ; 144,76 ; 635,97 ; 293,15$ tail; $4.79 ; 39.43 ; 50.20 \% ; 75.83 ; 80.77 ; 75.30 \%)$. The above data's as a basis for determining the measures to support sustainable agriculture.
\end{abstract}

Keywords - sustainable agriculture, invasion, colonization, Scirphopaga incertulas

\section{INTRODUCTION}

The arrangement of sustainable agriculture in Bali which appropriate with Bali government's mission: Bali Clean and Green "Go to Organic". The concept of modern agriculture looks like contradiction with the aspects of sustainable agriculture. The aspects of rice cultivation have been done by local agriculture community in Bali (call it SUBAK) for many years, but the attack of yellow rice stemborer still happen, which adverse farmer's side, persist.

Yield losses caused by the pest's attacks reach 125.000 tons per one season. In $2001-2011$ the area infected by rice stemborer attack in Bali reach 1.105; 1.672; 1.689; 1.872;
$1.724 ; 2.673 ; 1.265 ; 823.55 ; 1.223$ and 763.55 ha, with mild to severe intensity attack [3].

Until now, efforts to control which has been done by the farmers still rely on insecticides, but improper handling might cause the target pest become resistant, natural enemies are killed and poisoned, and also cause environmental pollution [2]. To avoid of negative effect due to the use of insecticide in controlling of insect pest on rice should be use another method. One alternatives of control method of rice stemborer was used of integrated pest management (IPM) concept. IPM is ecological approach. Biological control is one of the most important of IPM component such as the role of parasitoids. 
The egg parasitoids are often found associated with the rice stemborer are Trichogramma japonicum Ashm, (Hymenoptera: Trichogrammatidae), Telenomus rowani Gahan (Hymenoptera: Scelionidae) and Tetrastichus schoenobii Ferr (Hymenoptera: Eulophidae) [16]. Parasitoid of Trichogramma sp, Telenomus $\mathrm{sp}$ and Tetrastichus sp, were infected eggs of yellow rice stemborer on the plant ages of 4 week after planting were $40.00 \%, 31.52 \%$ and $28.48 \%$ [1]. [10] infected of yellow rice stemborer eggs by $\mathrm{T}$. schoenobii more than $50 \%$, T. rowani $15-18 \%$ and $2-8 \%$ of T. japonicum. The parasitoid of T. schoenobii, T. rowani and $\mathrm{T}$. japonicum were infected of yellow rice stemborer eggs with successive attack level $71 \%, 40 \%-98 \%$ and $20 \%$ [5], and [2] the parasitoid of Trichogramma sp and Tetrastichus sp were infected of a group eggs of white rice stemborer with attack levels between $7.5 \%$ to $38.0 \%$.

The understanding of the invasion and colonization of the parasitoid eggs as one component of efforts to control rice stemborer in paddy fields. That is very important in order to maintain the balance of natural enemies. The deeply understanding of the invasion and colonization that they have it as first step to determines the next steps to maintain a balanced population of parasitoids in sustainable agricultural systems. The information about the issue above were still limited, therefore research was conducted with the aim to understanding the invasion and colonization of the egg parasitoid of rice stemborer

\section{Methodology}

\section{A. Place and Time of Research}

The experiment was conducted in three Regency of endemic centers of yellow rice stemborer (Badung, Tabanan and Jembrana with 5 subak each Regency), and in the Laboratory of Plant Pests and Diseases Faculty of Agriculture, Udayana University since December 2013 to March 2014.

\section{B. Tools and Materials}

Tools and materials were used in this research included a sample group of yellow rice stemborer eggs, $\mathrm{KOH} 10 \%$, binocular microscope, preparat, the needle insects, spait, tweezers, paper, cotton, gauze, glass tube, tissue, Petridis, termohigrometer, loops, altimeter, camera and office stationery.

\section{Sampling Method}

The research was used survey method by taking a sample group of yellow rice stemborer eggs by purposive random sampling as many as 70 groups per week in an area of 2.5 acres at each Subak. Samples were taken at $10-66$ day plant age after planting by cutting leaves containing yellow rice rice stemborer eggs equal to 3 (three) $\mathrm{cm}$, then put in a plastic tube, labeled the location and the date they were taken and brought to the laboratory to take care for further identification.

\section{Methods of Observation}

The observations began the day after sampling until the parasitoid does not appear anymore. The observations was included the number of eggs that infected group, type of parasitoids that emerged, the number of stemborer larvae and adults of parasitoids that emerged. The group of eggs that did not hatch, dissection under the microscope to determine the borer larvae and adults of parasitoids that are still left in the eggs.

\section{E. Identification of Parasitoids}

The identification of parasitoids was done in step by step according to the sample group of eggs taken from the field, using a key determination.

\section{F. Observed Parameters}

The observed parameter was included the percentage of infected eggs, diversity, similarity, dominance, abundance, attack level and ratio of female parasitoids. The parasitoid species diversity were analyzed using the Shannon-Wiener index [12], the similarity of the Sorensen index [15], dominance by dominance index [7] and attack level with the Rauf model [14].

\section{G. Analysis of Data}

The data were analyzed by using a randomized block design (RBD). If the components in the test showed significant differences then will continue to the LSD test level of 5\%. The relationship between abundance population and parasitoid attack levels were analyzed by correlation analysis [4]. The results of the analysis are presented in tables, pictures and graphs.

\section{RESULTS AND DISCUSSION}

The result showed that the invasion and colonization of the egg parasitoid of yellow rice stemborer vary in Bali. The percentage of infected eggs, diversity, dominance, abundance population and attack levels of parasitoid were significantly different in the three Regency. The three types of parasitoids associated with rice plants, they are Trichogramma japonicum, Telenomus rowani and Tetrastichus schoenobii. More results are presented in the following table (Table 1-7) and the figure (Figure 1-2).

TABLE I

The Average Of Total Eggs Collected (Group) And The INFECTED (\%) AT THREE REGENCY IN BALI.

\begin{tabular}{lcc}
\hline Location & $\begin{array}{c}\text { The total of } \\
\text { eggs collected } \\
\text { (group) }\end{array}$ & $\begin{array}{c}\text { The percentage } \\
\text { of infected eggs } \\
(\%)\end{array}$ \\
\hline Badung & 70 & $83.68 \mathrm{~b}$ \\
Tabanan & 70 & $90.14 \mathrm{a}$ \\
Jembrana & 70 & $78.61 \mathrm{c}$ \\
\hline
\end{tabular}

Remarks: numbers followed by the same letter in the same column indicates no significantly difference at the $5 \%$ level LSD

In Table 1, the percentage of infected eggs was found highest in Tabanan $(90.14 \%)$, higher than the district of Badung (83.68\%) and Jembrana (78.61\%). 
TABLE II

The Average Of Diversity Index Of EgGs Parasitoid Yellow RICE STEMBORER AT THREE REGENCY IN BALI

\begin{tabular}{|c|c|c|c|}
\hline Location & Species & $\begin{array}{l}\text { Mean number of } \\
\text { species (t ail) }\end{array}$ & Diversity index type \\
\hline \multirow[t]{3}{*}{ Badung } & T. japonicum & 199.94 & \\
\hline & T. rowani & 471.14 & $0.42^{a}$ (Low) \\
\hline & T. schoenobii & 708.83 & \\
\hline \multirow[t]{3}{*}{ Tabanan } & T. japonicum & 96.16 & \\
\hline & T. rowani & 424.09 & $0.32^{\mathrm{c}} \quad$ (Low) \\
\hline & T. schoenobii & 1.193 .54 & \\
\hline \multirow[t]{3}{*}{ Jembrana } & T. japonicum & 144.76 & \\
\hline & T. rowani & 635.97 & $0.39^{b} \quad$ (Low) \\
\hline & T. schoenobii & 293.15 & \\
\hline
\end{tabular}

Remarks: numbers followed by the same letter in the same column indicates no significantly difference at the 5\% level LSD

Table 2 shows that, the parasitoid species diversity index in the three Regency has same lower level but actually they are real differences. The highest species diversity index was found in Badung (0.42) 31.25\% higher than the district of Tabanan (0.32) and 7.69\% of Jembrana (0.39).

TABLE III

The Average Of Similarity Index Of Egg Parasitoid Yellow RICE STEMBORER AT THREE REGENCY IN BALI

\begin{tabular}{lccc}
\hline Location & Badung & Tabanan & Jembrana \\
\hline Badung & - & $100 \%$ & $100 \%$ \\
Tabanan & $100 \%$ & - & $100 \%$ \\
Jembrana & $100 \%$ & $100 \%$ & - \\
\hline
\end{tabular}

Index of similarity of parasitoids in the three Regency have turned out to demonstrate the value that does not differences (100\% was same), but the dominance index values has different. The highest parasitoid dominance index in Badung was $T$. schoenobii followed $T$. rowani and $T$. japonicum, as well as at Tabanan, but at Jembrana the highest dominance index obtained $T$. rowani followed $T$. schoenobii and T. japonicum (Figure 1).

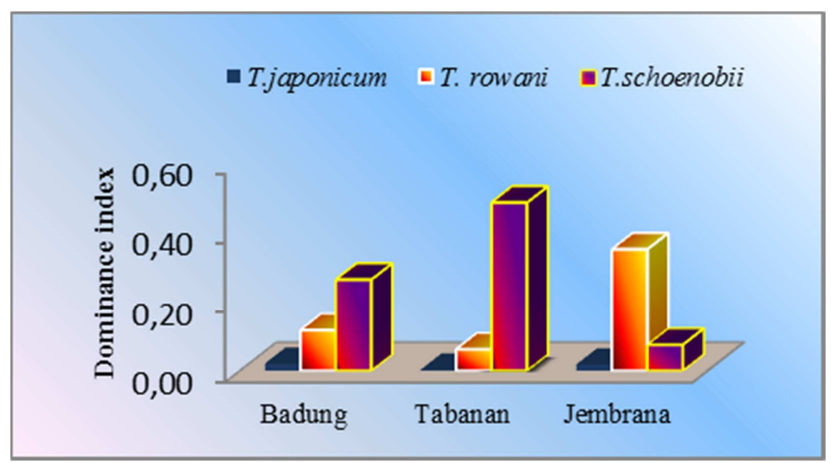

Fig. 1 Dominance index type of parasitoids
TABLE IV

THE AVERAGE OF ABUNDANCE POPULATION OF EGGS PARASITOID YELLOW RICE STEMBORER AT THREE REGENCY IN BALI

\begin{tabular}{|c|c|c|c|c|c|c|}
\hline \multirow{3}{*}{$\begin{array}{l}\text { Type of } \\
\text { Parasit oid }\end{array}$} & \multicolumn{6}{|c|}{ The abundance population of parasitoid } \\
\hline & \multicolumn{2}{|c|}{ Badung } & \multicolumn{2}{|c|}{ Tabanan } & \multicolumn{2}{|c|}{ Jembrana } \\
\hline & (tail) & $(\%)$ & (tail) & $(\%)$ & (tail) & $(\%)$ \\
\hline T. japonicum & $199.94^{\mathrm{c}}$ & $16.28^{\mathrm{c}}$ & $96.16^{\mathrm{c}}$ & $5.62^{\mathrm{c}}$ & $144.76^{\mathrm{c}}$ & $14.44 \mathrm{c}$ \\
\hline T. rowani & $471.14 \mathrm{~b}$ & $34.77^{\mathrm{b}}$ & $424.09 \mathrm{~b}$ & $24.89 \mathrm{~b}$ & 635.97 a & $57.18 \mathrm{a}$ \\
\hline T. schoenobii & 708.83 a & $48.95 \mathrm{a}$ & $1.193 .54 \mathrm{a}$ & $69.49 \mathrm{a}$ & $293.15 \mathrm{~b}$ & $28.38 \mathrm{~b}$ \\
\hline
\end{tabular}

The T. schoenobii was the highest abundance in Badung regency (708.83 tails), followed by $T$. japonicum (471.14 tails) and T. rowani (199.94 tails). The T. schoenobii was the highest abundance in Tabanan regency (1193.54 tails), followed by $T$. japonicum (424.09 tails) and T. rowani (96.16 tails). Meanwhile, $T$. rowani was the highest abundance in Jembrana regency (635.97 tails) followed by $T$. japonicum (293.15 tails) and T. schoenobii 44.76 tail (Table 4).

TABLE V

THE AVERAGE OF ATTACK RATE OF PARASITOID (\%) AT THREE REGENCY IN BALI

\begin{tabular}{|c|c|c|c|}
\hline \multirow{2}{*}{$\begin{array}{c}\text { Type of } \\
\text { Parasitoid }\end{array}$} & \multicolumn{3}{|c|}{$\mathrm{P}$ arasitoid attack rate $(\%)$} \\
\hline & Badung & Tabanan & Jembrana \\
\hline T. japonicum & $5.22 \mathrm{c}$ & $1.30 \mathrm{c}$ & $4.79 \mathrm{c}$ \\
\hline$T$. rowani & $20.61 \mathrm{~b}$ & $11.98 \mathrm{~b}$ & $39.43 \mathrm{~b}$ \\
\hline T. schoenobii & $64.25 \mathrm{a}$ & $85.13 \mathrm{a}$ & $50.20 \mathrm{a}$ \\
\hline
\end{tabular}

Remarks: numbers followed by the same letter in the same column indicates no significantly difference at the 5\% level LSD

Table 5 shows that the average rate of the highest attack in Badung was $T$. schoenobii $(64.25 \%)$ followed by $T$. japonicum $(20.61 \%)$ and $T$. rowani $(5.22 \%)$. Similarly, in Tabanan regency was $(85.13 \%, 11.98 \%$ and $1.30 \%)$ and Jembrana regency was $(50.20 \%, 39.43 \%$ and $4.79 \%)$.

TABLE VI

The Average Of Female Parasitoid Ratio (\%) At ThreE REGENCY IN BALI

\begin{tabular}{lccc}
\hline \multirow{2}{*}{ Location } & \multicolumn{3}{c}{ Female parasitoid ratio (\%) } \\
\cline { 2 - 4 } & T. japonicum & T. rowani & T. schoenobii \\
\hline Badung & $76.48^{\mathrm{a}}$ & $83.44^{\mathrm{a}}$ & $77.63^{\mathrm{a}}$ \\
Tabanan & $77.36^{\mathrm{a}}$ & $84.67^{\mathrm{a}}$ & $79.51^{\mathrm{a}}$ \\
Jembrana & $75.83^{\mathrm{a}}$ & $80.77^{\mathrm{a}}$ & $75.30^{\mathrm{a}}$ \\
\hline
\end{tabular}

Remarks: numbers followed by the same letter in the same column indicates no significantly difference at the 5\% level LSD

The mean ratio of the three types of parasitoid females at three Regency in Bali did not show significantly differences. The observation discovered a male female ratio of $T$. japonicum in Badung was 1:3.25, Tabanan was 1: 3.42 and Jembrana was 1: 3.14. The comparison of male female $T$. rowani in Badung was 1: 5.04, in Tabanan was 1: 5.53 and Jembrana was 1: 4.20 while the ratio of male female of $T$. schoenobii in Badung regency was 1: 3.47; Tabanan regency was 1: 3.88 and Jembrana regency was 1: 3.05 
TABLE VII

Agronomy ACTS OF FARMERS PERFORMED IN THREE REGENCY IN BALI

\begin{tabular}{|c|c|c|c|c|c|}
\hline Location & \multicolumn{2}{|c|}{$\begin{array}{l}\text { Without seed } \\
\text { treatment with } \\
\text { chemical / salt } \\
(\%)\end{array}$} & $\begin{array}{c}\text { Planting young } \\
\text { seedlings ( } 21 \text { days } \\
\text { down) }(\%)\end{array}$ & $\begin{array}{c}\text { Planted } 3 \\
\text { s plants / hole } \\
(\%)\end{array}$ & $\begin{array}{c}\text { Plant spacing } \\
(20 \times 20 \mathrm{~cm}) \\
(\%)\end{array}$ \\
\hline Badung & $84^{b}$ & & $72^{a}$ & $48^{b}$ & $40^{b}$ \\
\hline Tabanan & $100^{a}$ & & $64^{a}$ & $94^{a}$ & $100^{a}$ \\
\hline Jembrana & $96^{b}$ & & $74^{a}$ & $50^{b}$ & $86^{a}$ \\
\hline \multicolumn{6}{|c|}{ Continued } \\
\hline Location & $\begin{array}{l}\text { Rotatio } \\
\text { varietic } \\
\quad(\%)\end{array}$ & & $\begin{array}{c}\text { Cropping } \\
\text { pattern } \\
(\%)\end{array}$ & $\begin{array}{c}\text { Fertilizer } \\
\text { types } \\
\text { (types) }\end{array}$ & $\begin{array}{c}\text { Urea } \\
\text { fertilizer } 2 \mathrm{t} / \\
\text { ha }(\%)\end{array}$ \\
\hline Badung & $80^{a}$ & & $100^{a}$ & $3^{a}$ & $7.2^{b}$ \\
\hline Tabanan & $40^{b}$ & & $40^{b}$ & $3^{a}$ & $9.8^{a}$ \\
\hline Jembrana & $40^{b}$ & & $80^{a}$ & $2.6^{b}$ & $8.8^{a}$ \\
\hline \multicolumn{6}{|c|}{ Continued } \\
\hline Location & $\begin{array}{c}\text { Intermitte } \\
\mathrm{nt} \\
\text { irrigation } \\
(\%) \\
\end{array}$ & $\begin{array}{r}\text { Ty } \\
\text { pes } \\
\text { used }\end{array}$ & $\begin{array}{l}\text { ypes of } \\
\text { sticides } \\
\text { (types) }\end{array}$ & $\begin{array}{l}\text { quency of } \\
\text { use of } \\
\text { sticides } \\
\text { times) } \\
\end{array}$ & $\begin{array}{c}\text { Dose of } \\
\text { pesticides per } \\
\text { hectare of land } \\
(\mathrm{ml} / \mathrm{mg}) \\
\end{array}$ \\
\hline Badung & $100^{a}$ & & $16^{b}$ & $.90^{b}$ & $867^{b}$ \\
\hline Tabanan & $100^{a}$ & & $16^{a}$ & $.06^{\mathrm{a}}$ & $892^{b}$ \\
\hline Jembrana & $100^{a}$ & & $86^{b}$ & $.30^{b}$ & $1409^{a}$ \\
\hline
\end{tabular}

Remarks: numbers followed by the same letter in the same column indicates no significantly difference at the 5\% level LSD

\section{THE RELATIONSHIP BETWEEN ABUNDANCE POPULATION AND PARASITOID ATTACK LEVEL}

Figure 2, it appears the relationship of abundance populations with attack level of parasitoid in each Regency. T. schoenobii highest abundance population in Badung regency (708.83 tails), followed by $T$. rowani (471.14 tails) and T. japonicum (199.94 tails). T. schoenobii highest abundance population in Tabanan regency (1193.54 tails), followed by $T$. japonicum (424.09 tails) and $T$. rowani (96.16 tails). (Table 4). Meanwhile, T. rowani highest abundance population in Jembrana regency (635.97 tails) followed by $T$. schoenobii (293.15 tails ) and T. japonicum (144.76 tails) (Table 4), while $T$. schoenobii attack highest level in Badung regency (64.25\%) followed by $T$. rowani (20.61\%) and T. japonicum (5.22\%). Likewise, in the district of Tabanan and Jembrana are 85.13; $11.98 ; 1.30$ and 50.20; $39.43 ; 4.79 \%$ (Table 5). Based on the analysis of correlation between abundance population and the parasitoid attack rate showed that the high abundance of the population has a very strong positive relationship $(\mathrm{r}=0.95 ; 0.99 ; 0.99)$ for the high parasitoid attack $T$. japonicum, $T$. rowani and $T$. schoenobii respectively.

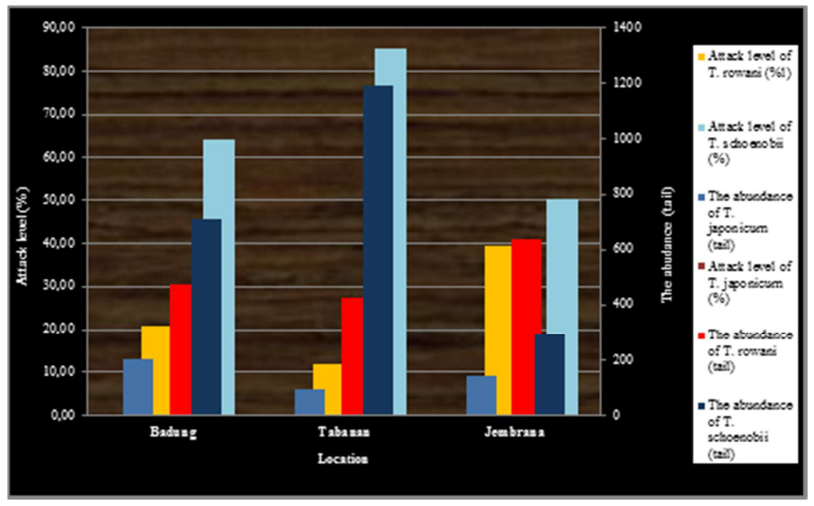

Figur 2. The relationship between abundance population and parasitoid attack level

The invasion and the colonization parasitoids of yellow rice stemborer in Bali is vary and differ on several variables were observed and shown as follows: the percentage of infected eggs, abundance population, attack rate, diversity and dominance of the parasitoid.

The highest percentage of developing eggs group found in Tabanan, followed by Badung and Jembrana regency (Table 1). A similar incident also found in a variable abundance population and parasitoid attack rate (Tables 4 and 5). The high percentage of developing eggs group, abundance population and parasitoid attack rate in Tabanan regency closely related to agronomic acts as extrinsic factors. Following the agronomic question include seed treatment, planting young seedlings ( 21 days down), planting 3 plants in one hole, plant spacing, rotation varieties, cropping patterns, type of fertilizer, urea, irrigation and pesticide used (type, frequency and dose, with correlation value $r=0.79$; $0.79 ; 0.77$ each for rotation varieties, cropping patterns and types of pesticides (Table 7). The Parasitoid abundance population is influenced by intrinsic factors such as individual adaptability of parasitoids to host and extrinsic factors (environmental support) such as nutritional quality of the host and the host plant biophysical constraints that affect the host-seeking behavior and nesting parasitoid on the host, besides farming practices such as spraying intensity and use of broad-spectrum pesticides by farmers also give a great influence on the lives of parasitoids in the field [17].

Parasitoid species diversity in the three study sites demonstrate the value of diversity is relatively low at $<1.5$ (Table 2). The low value is due to the low number of species and number of individuals per species found during the study. In Bali only three species of parasitoids associated with rice plants. Actually 35 species of parasitoids associated with rice plants [9]. The low diversity is also closely related to the follow agronomic farmers, such as the use of pesticide. The low diversity of parasitoids also because the ecosystems are physically controlled by the actions of cultivation by the farmers [8]. Similarly, [11] stated that diversity tends to below when the ecosystem or physically controlled by the location of cultivation by farmers. Existence of human activity also gives the affect of diversity of species in an ecosystem [13].

The further of research analyze found that among the third of diversity low value index that have diversity index varian. 
The highest diversity index values obtained in Badung regency and the lowest one in Tabanan regency (Table 2). The incident was caused by avariation in the number of individuals per species (Table 2). These events are also supported by the development of evenness variation parasitoids during the rice growth (age 10 - 66 dap). The development of three types of parasitoids in Badung varied and turns during plant growth, while in Tabanan was was dominated by one type of parasitoid T.schoenobii. [11], when the diversity is low, the species parasitoid can become the dominant species and otherwise, when the high diversity the species can not be dominant. The value diversity will tend to be low if the community is dominated by a single species [6].

The results of the analysis of similarity type and ratio of female parasitoids in three locations showed no significantly differences (Tables 3 and 6), but the dominance of the parasitoid for each Regency has a dominant parasitoid. Figure 1 shown that $T$. schoenobii dominate in Tabanan and Badung, while in Jembrana by $T$. rowani. The dominance of one species showed a high population compared with other species present in an area. The high population of $T$. schoenobii at Tabanan and Badung caused by environmental factors are suitable for development. Similarly, T.rowani in Jembrana.

The abundance population of parasitoid has a strong correlation with the level of attack (Figure 2). The higher abundance caused the higher of population, but the lower abundance or vice versa the lower of attack level. Parasitoid attack rate is influenced by environmental factors.

\section{CONCLUSIONS}

The invasion and the colonization of the egg parasitoid of yellow rice stemborer in Bali is vary in diversity, dominance, abundance population, the percentage of infected eggs and attack level. This understanding is as a basis for determining the measures to support sustainable agriculture.

\section{ACKNOWLEDGMENT}

Thank you to the observer pests agriculture in Badung, Tabanan and Jembrana regency and the co-workers for their help during the study.

\section{REFERENCES}

[1] Agus, N. "Biologi Parasitoid Telur Trichogramma sp. (Hymenoptera: Trichogrammatidae) dan Telenomus sp. (Hymenoptera: Scelonidae) pada Penggerek Batang Padi Kuning Scirpophaga incertulas Walker (Lepidoptera: Pyralidae)".thesis, InstitutPertanian Bogor, Bogor. 1991.

[2] Arifin , K.. "Penggunaan Musuh Alam Sebagai Komponen Pengendalian Hama Padi Berbasis Ekologi". Peng. InovPert ., vol. 4, pp. 29-46, 2011.

[3] BPTPH Bali. Balai Proteksi Tanaman Pangan dan Hortikultura (BPTPH) Provinsi Bali, 2012. Laporan Pelaksanaan Kegiatan Balai Proteksi Tanaman Pangan Tahun Anggaran 2011/2012. 2011.

[4] Gomez, K.A.\& A.A. Gomez. Prosedur Statistik untuk Penelitian Pertanian. Diterjemahkan oleh Syamsuddin, E. \& J.S. Baharsyah. Jakarta: Universitas Indonesia Press. 1995.

[5] Laba, IW. " Prospect of Egg Parasitoids as Natural Enemies of Rice Stem Borer”. J. Penelitiandan Pengembangan Pertanian, vol. 17, pp.14-22., 1998.

[6] Maguran, A.E. Ecological Diversity and Its Measurement. Cambridge: Cambridge University Press, 1988.

[7] Michael. Metode Ekologi untuk Penyelidikan Lapangan dan Loboratorium. Diterjemahkan oleh Koestoer, Y.R. \&S.Suharto. Jakarta: Universitas Indonesia Press, 1995.

[8] McPheron, B.A. \& G.J. Steck. A World Assessment of Their Biology and Management. Overview of research on the behavior of fruit flies. In Fruit Fly Pests. Florida: St Lucie Press, 1996.

[9] Nickel, J.L..Biological Control of Rice Stem Borers. IRRI. Los Banos, Laguna, Philippines. 1964.

[10] Nurbaeti, B., E. Soenaryo \& Waluyo. "Parasitism of Egg Parasitoid of Yellow Rice Stemborer (YRSB) Scirpophaga incertulas Walker (Lepidoptera: Pyralidae). J. Pen. Tan. Pangan, vol. 4, pp 270-276, 1994.

[11] Oka, IN. Pengendalian Hama Terpadu dan Implementasinya di Indonesia. Yogyakarta: Gadjah Mada University Press, 1995.

[12] Odum. E.P. Dasar - dasar Ekologi. Edisi ketiga. Terjemahan. T. Samingan Yogyakarta: Gajah Mada University Press, 1998

[13] Ricklefs, R.E. \& D. Schulter. Species Diversity In Ecological Communities. London: The University of Chicago Press, 1993.

[14] Rauf, A. "Parasitisasi Telur Penggerek Batang Padi Putih Scirpophaga innotata Walker (Lepidoptera: Pyralidae), SaatTerjadiLedakan Di Kerawang Pada Awal 1990-an". Bul. HPT.,vol.12, pp 1-10, 2000.

[15] Southwood, T.R.E. Ecological Methods with Particular Reference to Study of Insect Population. London: Chapman and Hill. 1980.

[16] Supartha, IW.“ Kelimpahan Populasi dan Peranan Parasitoid Telur dalam Pengaturan Populasi Penggerek Padi Kuning pada Pertanaman Padi Sawah di Bali”. Agritop. J. Agric. Sci., vol. 20, pp 75-79, 2001.

[17] Supartha, IW., IG. N. Bagus \& P. Sudiarta ."Kelimpahan Populasi Liriomyzaspp. (Diptera: Agromyzidae) dan Parasitoid pada Tanaman Sayuran Dataran Tinggi”.". Agritop. J. Agric. Sci., vol. 24, pp 43-51, 2003 